\title{
Calling for Authentic Leadership: The Moderator Role of Calling on the Relationship between Authentic Leadership and Work Engagement
}

\author{
Victor Seco, Miguel Pereira Lopes \\ Social and Political Sciences Institute, University of Lisbon, Lisbon, Portugal \\ Email: victor.seco@gmail.com, mplopes@iscsp.ulisboa.pt
}

Received October $19^{\text {th }}, 2013$; revised November $18^{\text {th }}, 2013$; accepted November $25^{\text {th }}, 2013$

\begin{abstract}
Copyright (C 2013 Victor Seco, Miguel Pereira Lopes. This is an open access article distributed under the Creative Commons Attribution License, which permits unrestricted use, distribution, and reproduction in any medium, provided the original work is properly cited.
\end{abstract}

\begin{abstract}
Authentic Leadership (AL) literature supports the existence of a positive relationship between perceived $\mathrm{AL}$, follower work engagement, and positive attitudes like calling. Our research doesn't confirm that relationship and fosters the possibility of AL influence could not be felt by employees. It was also expected, theoretically, a positive effect of Calling as well as with trust. We have found a significant negative effect on the relationship between AL and calling. But our findings brought some positive insights. There was a positive significant relationship between calling and work engagement. Calling had also moderated, with a positive significant result, the relationship between $\mathrm{AL}$ and work engagement. Future research should focus on the importance of perceived AL within the education public services, and the significant effect of calling on work engagement. Our study suggests that organizations could promote employee calling work orientation, stimulate leaders to become more authentic, and improve positively organization performance.
\end{abstract}

Keywords: Work Engagement; Authentic Leadership; Work Orientations; Calling

\section{Introduction}

People need to believe and trust their leaders more than ever. Believing, as in Gilbert (1991), involves the knowledge and mental representation of significant information, which is regarded as truthful. The authenticity of the leader in exercising his/her positive qualities of character will be the beacon that help people to face the growing complexity and trust deficit that storms the present day. That is why, from the bankruptcy of several global firms (Enron, Northern Rock, Lehman Brothers) and the noticeable lack of honesty on the part of their leaders, a new focus of interest in the study of leadership has emerged that in turn has led both researchers and professionals in management towards the now renamed "authentic leadership" (AL).

Leaders often underestimate the challenge of engaging employees but it is becoming increasingly important, given that disengaged employees represent a high cost to the organizations (Avery, McKay, \& Wilson, 2007). Employee engagement has a direct effect on performance (Harrison, Newman, \& Roth, 2006).

Authentic leadership is positively related to engagement as authentic leaders strengthen the feelings of self-efficacy, competence and confidence of their followers, as well as the identification with the leader and the organization, which results in higher levels of engagement (Avolio \& Gardner, 2005; Gardner, Avolio, Luthans, May, \& Walumbwa, 2005). On this topic Cartwright and Holmes (2006: p. 206) argue that: "As individuals become increasingly disenchanted and disillusioned with work and fatigued by the constant demand to change and to be flexible in response to organizational needs, employers now need to actively restore the balance, recognize the meaning and emotional aspects of work and move towards creating a more energized, fulfilled and engaged workforce".

From a professional's perspective of AL, Bill George (2007) gave the motto and, in his book "True North, Discovering your authentic Leadership", used a very effective metaphor for presenting the importance of authenticity: top executives should use their internal compass to find and follow the True North in the business world. On the other hand, researchers such as Luthans and Avolio (2003), helped to improve the AL construct by defining it as "a process that draws from both positive psychological capacities and a highly developed organizational context, which results in both greater self-awareness and self-regulated positive behaviors on the part of leaders and associates, fostering positive self-development" (p. 243). This alternative of leadership is immersed in a specific field of psychology known as Positive Psychology focusing on the study and appreciation of forces, virtues and the most positive aspects of life, converging on the development of people, self-realization and meaning of life (Seligman \& Csikzentmihalyi, 2000). Positive Psychology emphasizes the study of grace, excellence and authenticity and raises their importance as determinants for life to the level of diseases, disorders or anxieties (Peterson \& Seligman, 2003). Also, the study of work engagement is regarded by Positive Psychology as very important.

We are aware that when we study leadership we must not forget followers. They follow those who lead, not for them, but for a greater good. As Kets de Vries (2001: p. 107) argues, 
"meaningful activity at work becomes a way to transcend personal concerns; it becomes a way to create a sense of continuity. Leaving behind a legacy through work becomes an affirmation of the person's sense of self and identity; it can become an important form of narcissistic gratification". Meaningful work fosters the employees' self-esteem, hope, health, happiness and sense of personal growth (Csikszentmihalyi, 2003).

In the specific case of schools, teachers are followers, working for the greater good of society, but need to be highly engaged in their job, because dealing with young people and their specific traits is not easy and entails more than merely a salary in return for their work. It is far more than simply a well-paid job and a structured career. Working in a mass public school requires a special kind of dedication and a humanitarian orientation, caring for young people, shifting their future. When teachers feel that the organization cares for and is helpful to the community, they feel that they are performing meaningful work. Chalofsky (2003) has consistently demonstrated that people rate purpose, fulfillment, autonomy, satisfaction, close working relationships and learning as more important than money. Frankl (1984) said that the "search for meaning is the primary motivation in life". The present paper extends the study of the relationship between AL and Work Engagement and focuses on an additional construct which is Work Orientations. This study will be endeavored from the followers' standpoint. To achieve this, correlations are sought between the dimensions of those constructs, based on answers given by public secondary school teachers. This paper is structured as follows. First, a description of the constructs under evaluation is given: Work Engagement, $\mathrm{AL}$ and Work Orientations. Next we present hypotheses correspondent to the proposed theoretical model. This includes the analysis of the relationship between AL, Work Engagement and Work Orientations, namely of its component Calling. The objective is to capture relationships between authentic leadership and work engagement characteristics and the essence of work orientations. Finally, the usual format is followed: method, results, discussion and conclusions. The main limitations of this research and suggestions for future studies are also explored.

\section{Work Engagement}

Work engagement is an important conceptualization of adults' happiness and well-being at work. Engagement refers to the relationship the employee has with his work; the better the relationship, the greater the level of engagement (Schaufeli \& Salanova, 2011). This construct reflects a Positive Psychology trend defined in 2002 by Schaufeli, Salanova, Gonzáles-Romá and Bakker as "a positive, fulfilling, work-related state of mind that is characterized by vigor, dedication and absorption" (p. 74).
Vigor refers to "high levels of energy and mental resilience while working", i.e., the will and persistence of someone who is engaged with the work. Dedication is defined as a strong involvement in one's work and a fulfilled meaning of it. Absorption means the concentration and happiness felt in one's work that helps time pass quickly. Work engagement has a close relationship with a phenomenon that has been studied for a quarter of a century, the burnout syndrome. While burnout is caused by deterioration of working health, work engagement is associated to a process of improving that working health. According to a recent review, work engagement is positively associated, for instance, with mental and psychosomatic health, intrinsic motivation, efficacy beliefs, positive attitudes towards work and the organization, and high performance (Schaufeli \& Salanova, 2007). According to Buskist, Benson and Sikorski (2005), teachers who have a call presented different work engagement behaviors, namely: 1) demonstrated a broad and in-depth knowledge of the subject to teach; 2) turned relevant the knowledge on the day-to-day issues; 3) emphasized the critical thinking on the part of students; and 4) shared with each other their values, trivia and academic enthusiasm.

\section{Authentic Leadership}

AL emerged as an important component in positive leadership studies since its initial conceptualization in the late seventies, until its theoretical maturity was proposed as a "root construct of leadership theory" (Gardner, Avolio, \& Walumbwa, 2005: p. 315). The construct AL was initially proposed by Luthans and Avolio (2003) and was developed by Gardner et al. (2005) and Avolio and Luthans (2006). However, Avolio, Gardner, Walumbwa \& May (2004) were the first to propose this as a theoretical model derived from the positive organizational behaviour, in which leaders are deeply aware of how people think and behave, the context in which they operate and are perceived by others, as well as of values/morals systems, knowledge, perspectives. They are also conscious of their own strengths as well as of that of others. In AL, there are four characteristic dimensions that describe the behavior of the leaders and allow them to be recognized as authentic as shown in Table 1.

This way the theoretical model of AL includes not only leader behaviours but also their characteristics as well as that of their followers, such as their levels of psychological capital, suggesting a more integrated approach to the study of leader ship and organizational behaviour (Gardner et al., 2005; Luthans, Norman, \& Hughes, 2006). Authentic leaders are those "who know who they are and know what they believe in (Avolio, Gardner, \& Walumbwa, 2005: p. 13). When leaders are

Table 1.

AL characteristic dimensions.

\begin{tabular}{cl}
\hline \multicolumn{1}{c}{ Dimensions ${ }^{1}$} & \multicolumn{1}{c}{ Description } \\
\hline Relf-awareness & $\begin{array}{l}\text { Refers to the knowledge that the leader has about his or her strengths and weaknesses. } \\
\text { It has to do with the characteristics of the leader, generating a climate of trust among the followers that } \\
\text { allows for the sharing of thoughts and emotions. } \\
\text { Refers to the leader's capability to set and show goals and carefully examine relevant information before } \\
\text { making a decision. } \\
\text { Relates to self-regulation behaviour according to personal values and principles when facing group, } \\
\text { organization or society pressures. }\end{array}$ \\
\hline
\end{tabular}

${ }^{1}$ Adapted from Walumbwa et al., 2008: pp. 95-96). 
aware of how their own actions affect those who are around them, being open and transparent to the processes and influences within and outside of their organizations, the followers have a better sense of the organizational goals/challenges. Hence, a measure of AL will be based not only on the followers' perceptions as well as those of the leaders (Authentic Leadership Questionnaire, Walumbwa et al., 2008). Nonetheless, AL is emerging as an alternative perspective of leadership in different organizational settings including education. In terms of education it is the work of Paul Begley that is most associated with AL (Begley, 2001, 2006). Often values-based literature on AL has also been attributed to the work of Robert Starratt (2004). Begley (2006) proposes three prerequisites to AL in schools: self-knowledge, a capacity for moral reasoning, and sensitivity to the orientation of others.

Duignan (2007), referring to an authentic approach to educational leadership, argues "that while authentic leadership focuses on ethics and morality in actions and interactions, it must also promote and support the core values of schooling, that is, educative and authentic teaching and learning".

So, "Authentic educative leaders challenge others to participate in a visionary dialogue of identifying in curriculum, teaching and learning (especially pedagogy) what is worthwhile, what is worth doing (moral purpose) and preferred ways of doing and acting together".

You can't expect great AL results in contexts in which trust is shaken. However, it is in times of crisis that people discover ways to prepare the future better. Thus, we are convinced that self-awareness is absolutely fundamental in building great organizations. You cannot be emotionally intelligent if you are not also self-aware. This requires, in addition to maturity, intense work of self-examination or individuation. Criticisms, even the toughest, are essential for the construction of selfawareness. To do so, you need to get honest feedback from followers, i.e. the followers must also be authentic.

Especially in public schools, teachers have great need for someone that listens, understands and, above all, tells them the truth. If we practice authenticity, it is in teamwork, in the department, that such support appears. Authentic leaders have to maintain high levels of motivation especially in this era of "trigger events". Such extrinsic motivation will help if it is seen as an opportunity to change the future and make it better.

\section{Work Orientations}

Employees increase their commitment and quality of life due to satisfaction at work (Loscoco \& Roschelle, 1991; Wrzesniewski, McCauley, Rozin, \& Schwartz, 1997). People who consider their work as a Job live (?) simply to earn money, as that allows them to do whatever they wish to do outside of their job. They have little investment and gain little satisfaction other than the paycheck. As Wrzesniewski et al. (1997) said, "The major interests and ambitions of Job holders are not expressed through their work" (p. 22). When work is perceived as a job, people look forward to taking a break, finishing work, the weekend, public holidays, and vacations. Outside of their working hours, little or no thought, time, or energy is devoted to work. On the other hand, people who believe that the most important thing in their life is their Career place importance not only on the money they can possibly earn, but also on their ability to climb to the upper realms of power or make decisions within their organization. A career is perceived as a progression of continuous improvement through pay raises, promotions, better opportunities and experiences regarded as essential to ongoing advancement. People commit themselves to working far beyond the normal workday, during evenings, weekends, and vacations. As such, they "have a deeper personal investment in their work and mark their achievements" (Wrzesniewski et al., 1997: p. 22). Coetzee (2008) recently presented a valuable theoretical framework (career enablers, career drivers, career harmonizers, career preferences and career values) to help individuals recognize the significance of developing their inner career resources and drawing on these psychological resources to improve their universal employability characteristics and abilities. Last but not the least, we refer to Calling as the way people live to work. Their work is something that simply fulfills their lives. They are unconcerned with earnings or career advancements. A calling is work that a person feels called to do by a higher power. Work that is a calling feels as if it both contributes to humanity and is also in line with an individual's purpose in life. Characteristically, people perceiving their work as a calling indicate they would do the work for little or no pay. That is how satisfying it is. Bunderson and Thompson (2009) concluded that people feel calling "as a cause rather than as a consequence of choices and sacrifices" so "individuals develop an early sense of their gifts and interests, which leads them to certain types of work, which in turn motivates them to justify their choices, which in turn deepens their occupational commitment, and so on" (p. 53). For those individuals, it is the work itself which provides satisfaction, rather than any external recognition or reward. People "find that their work is inseparable from their life" (Wrzesniewski et al., 1997: p. 22).

In an article suggestively named "The Call to teach", Buskist et al. (2005) reported that the performance and well-being of teachers and students depend to a large extent on how teachers see their profession as a call.

Dobrow (2007: p. 4) argued that some authors have dealt with the sense of calling and differently named, but related, constructs: 1) work orientations, including a calling orientation (Wrzesniewski et al., 1997); 2) work preferences, particularly intrinsic motivation (Amabile et al., 1994); 3) a discerned, conscious sense of calling (Weiss, Skelley, Haughey and Hall, 2003; Hall and Chandler, 2005); and 4) work engagement and flow (Csikszentmihalyi, 1990; Kahn, 1990; May, Gilson, and Harter, 1999). Dobrow (idem) suggested that domain-specific self-esteem, "one of the psychological conditions of work engagement", i.e., "people's feelings about their abilities", is a very important calling component (p. 6). The author considered seven calling "core elements: passion, identity, urgency, engulfs consciousness, sense of meaning, domain-specific selfesteem and a subjective sense of longevity" (p. 7).

\section{Hyphoteses}

We expected, as in specialized literature, AL positive influence on work engagement. Then, we explored the novelty of the positive relationship between $\mathrm{AL}$ and Calling according to Positive Psychology study and appreciation of forces, virtues, self-realization and meaning of life. We also studied the positive relationship between Calling and Work Engagement. Finally, we assumed that Calling could foster the relationship between AL and Work Engagement. The theoretical model used in this study is presented in Figure 1. 


\section{Leaders' Authentic Leadership as a Predictor of Teachers' Work Engagement}

Toor and Ofori (2008: p. 620) give the following description of authentic leaders: "Authentic project leaders possess positive values, lead from the heart, set the highest levels of ethics and morality, and go beyond their personal interests for the well-being of their followers. They capitalize on the environment of trust and are able to motivate people and accomplish challenging tasks." Authentic leaders are stated as role models by Avolio and Gardner (2005) as "leading by example" (p. 326). So we can infer that AL causes the transformation of followers, however, this occurs because of the transparency of the leader and not because of deliberate actions with the objective to change followers (Avolio \& Gardner, 2005). Authentic leaders also foster authenticity among their subordinates, feel less threatened by the changes that employees' genuine/creative ideas may imply and are more inclined to welcome their creative suggestions (Michie \& Gooty, 2005).

H1: Leaders' Authentic Leadership is positively associated with teachers' work engagement.

\section{Authentic Leadership as a Predictor of Teachers' Calling}

Avolio \& Gardner (2005) and later Spitzmuller \& Ilies (2010) described authentic leadership, transformational leadership, charismatic leadership, and spiritual leadership as positive leadership styles. They explained that these different positive leadership styles are very close in meaning and understanding. However, authentic leadership is considered to be the root concept of positive leadership styles. Thus, authentic leadership can incorporate other leadership styles. Avolio \& Gardner (2005) and Spitzmuller \& Ilies (2010) outlined that both transformational and charismatic leadership deliberately focuses on the follower and his actions. Transforming the follower and making the follower identify with the leader are the objectives. Csikszentmihalyi's research on flow (1990) has found that the activities that foster optimal experiences, which can be viewed as episodic manifestations of a calling, are characterized by being challenging and requiring appropriate skills.

H2: Leaders' Authentic Leadership is positively associated with teachers' calling.

\section{Teachers' Calling as a Predictor of Teachers' Work Engagement}

Wrzesniewski et al. (1997) found that calling orientation was strongly linked to life and job satisfaction. According to Dobrow (2007: p. 7) calling is consists of the following core elements: 1) passion; 2) identity; 3) urgency; 4) engulfs consciousness; 5) sense of meaning; 6) domain-specific self-esteem, and 7) a subjective sense of longevity. The author (p. 6) consid-

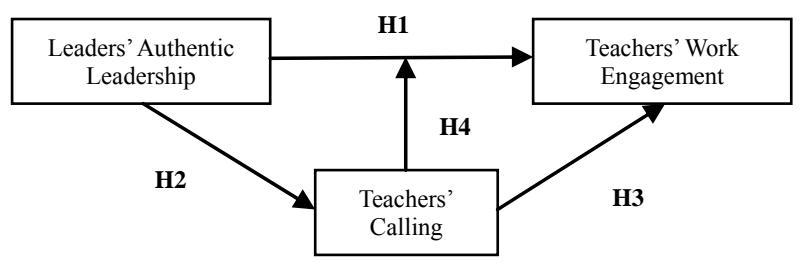

Figure1.

Hypothesized theoretical model. ered the domain-specific self-esteem as crucial in calling construct. She quotes the importance of people's subjective perceptions of their abilities in work engagement and includes it in the characterization of "flow-encouraging activities" from Csikszentmihalyi.

H3: Teacher's calling is positively associated with teacher's work engagement.

\section{Teachers' Calling as a Moderator of the Relationship between Leaders' Authentic Leadership and Teachers' Work Engagement}

Wrzesniewski et al. (1997) found that calling orientation was strongly linked to life and job satisfaction. In their study, Bakker, Albrecht and Leiter (2011: pp. 7-8) considered that "personal resources like self-esteem, optimism, and self-efficacy help employees to cope with the daily demands in organizational life." They also consider the "climate for engagement" where employees are "more likely to respond by investing time and energy and by being psychologically involved in the work of their organization" (p. 13).

H4: Teachers' calling moderates the relationship between Leaders' Authentic Leadership and teachers' work engagement.

\section{Method}

\section{Data and Sample}

Data was collected by handing out a questionnaire containing questions for three different organizational behaviour variables. Data collection was done by handing out personally self-administered surveys. This means that those who received the questionnaire were not compelled to participate. Due to the sensitive nature of the questions on the behavior of the leader, we included a section in the introduction of the questionnaire in which we emphasized the anonymous and confidential nature of the analysis of results. The population which received the questionnaire was a non-probability convenience sample because we distributed the questionnaire in a wide range of schools in the northern coast of Portugal. The dataset contains data from 326 respondents, followers that know and frequently meet their leader, between the age of 31 and 62. Among the employees, or followers, who filled in the questionnaire, $24.2 \%$ were male and $75.8 \%$ were female, which is a normal percentage in education research.

\section{Measures}

Authentic Leadership-We have used the 16-item scale translated into Portuguese to measure the independent variable Authentic Leadership (AL), called the Authentic Leadership Questionnaire (ALQ) which is formed and was tested by Walumbwa, Avolio, Gardner, Wernsing, and Peterson (2008) and has been widely used in research. Some sample items are: 1) Accurately describes how others view his or her capabilities (self-awareness); 2) Listens carefully to different points of view before coming to conclusions (balanced processing); 3) Demonstrates beliefs that are consistent with actions (internalized moral perspective); 4) Says exactly what he or she means (relational transparency).

The followers' perception of the authentic leader is used to measure AL as it is often explained that the perception of the leader by the follower determines the existence of a leader and 
his effectiveness, and the perception possibly differs when different values are maintained by the follower (Lord \& Maher, 1994; Yan \& Hunt, 2005). The original Cronbach's Alfa of this measure was .84 and for our sample it was .89. Employees were asked to report the frequency (0: "not at all"; 4: "frequently, if not always") with which their supervisors adopted the 16 behaviours. We conducted a Principal Components Analysis (PCA) and we obtained a medium Kaiser-Meyer-Olkin (KMO) Measure of Sampling Adequacy of .710. After the PCA was checked for suitability, the analysis showed that it is suitable to use the scale as measuring one core factor which explained $41.23 \%$ of the variance. As the total variance table shows, there are four possible components that explained $73.636 \%$ of the total variance. This finding was supported by the scree plot which showed a clear break after the first component and the component matrix revealed that all items load on component one (Cattell, 1966; Pallant, 2007). We computed an overall AL score as it is more appropriate, which is consistent with the findings of Walumbwa et al. (2008).

Work Orientations - We measured work orientations using a translated adaptation of the "University of Pennsylvania WORK-LIFE questionnaire" used by Wrzesniewski et al. (1997). We translated the 18 items into Portuguese asking about specific aspects of relationships at work ignoring the authors' true-false proposition. Some sample items are: 1) "My work makes the world a better place" (calling); 2) "I am eager to retire" (job); 3) "I view my job primarily as a stepping stone to other jobs" (career). A five-point Likert-type scale with 1 being "strongly disagree" and 5 being "strongly agree" was used for the subjects' responses to each of the 18 items. We also conducted a Principal Components Analysis (PCA) and we obtained a non-acceptable Kaiser-Meyer-Olkin (KMO) Measure of Sampling Adequacy of .341. Thus, we decided to consider only the Calling component in the present research and its estimated Cronbach's alpha was .696.

Work Engagement-Follower engagement was measured using the 9-item scale, translated into Portuguese, Utrecht Work Engagement Scale (UWES), free for use for non-commercial scientific research, formed and tested by Schaufeli and Bakker (2003), which originates in the 17-item UWES. Some sample items are: 1) "At my work I feel I am bursting with energy" (vigor); 2) "My job inspires me" (dedication); 3) "I feel happy when I am working intensely" (absorption). These items used a seven-point Likert scale with 0 being "never" and 6 being "always". Within the present research the estimated Cronbach's alpha was .94 (Schaufeli, Bakker and Salanova, 2006; Cronbach's $\alpha=.89$ ). The PCA was used to measure the higher order structure of the 9-item scale of follower engagement as well. After checking the suitability of the analysis, the test showed that the scale measured one core factor explaining $68.67 \%$ of the variance. Additionally, the scree plot showed a clear break after the first component and the factors loaded strongly on the first component (Cattell, 1966; Pallant, 2007). We computed an overall work engagement score as recommended by Schaufeli et al., 2006.

Control variables - In every analysis, time of work with current leader, service time in school and age of the respondent were controlled because of their possible influence on the outcome variables included in the present research. These variables were included in the demographics section of the questionnaire.

\section{Data Analysis}

A hierarchical multiple regression analysis was used to evaluate the relationship between leaders' authentic leadership, from the point of view of the followers, and follower calling and work engagement and to test calling for moderation. This analysis accounts for the step by step inclusion of controlling, independent, dependent, and moderating variables in the analysis (Hox, 2002; Pallant, 2007). The independent and dependent variables and the moderator variable in this study were individual-level variables. In the analysis, the hypotheses were tested in three steps. In the first step, the control variables (i.e. time of work with current leader, service time in school and age of the respondent) were considered. In the second step, the independent variable (i.e. perceived authentic leadership) and Calling were entered. In the third step, the independent variable (i.e. perceived authentic leadership) and the moderator variable (i.e. calling) were entered.

\section{Results}

\section{Descriptive Results}

Table 2 contains descriptive statistics and bivariate correlations for all study measures included in the present research. The amount of males and females in the sample reflected the normal settlement of gender distribution in the education sector $(\mathrm{M}=1.76, \mathrm{SD}=.43)$.

Test of Hypotheses-Tables 2 and $\mathbf{3}$ both show results to test the stated hypotheses. Table 2 shows the correlations among the variables; Table 3 contains the results of the hierarchical regression analysis of the two dependent variables (i.e. work engagement and calling). Table 2 shows significant correlations between perceived authentic leadership and calling ( $\mathrm{r}$ $=-.25, p<.01)$, time of work with current leader $(\mathrm{r}=.27, p<$ $0.01)$, and service time in school $(\mathrm{r}=.17, p<.01)$. We must also refer the significant correlation between calling and work engagement $(\mathrm{r}=.56, p<.01)$. The results of the hierarchical multiple regression analysis in Table 3 are used to test the stated hypotheses. Step 1 shows that the controlling variables (i.e. age, time of work with current leader, and service time in school of the followers) have significant statistical influence on work engagement $\left(\Delta \mathrm{R}^{2}=.10, p<.001\right)$. Including the independent variable, perceived authentic leadership, and work engagement and calling in step 2 led to a significant shift in variance explained by the dependent variable calling $\left(\Delta \mathrm{R}^{2}=.08\right.$,

Table 2.

Means, standard deviations, and correlations among study variables.

\begin{tabular}{ccccccccc}
\hline Variable $^{2}$ & $\mathrm{M}$ & $\mathrm{SD}$ & 1 & 2 & 3 & 4 & 5 & 6 \\
\hline 1. AL & 2.99 & .67 & 1.00 & & & & & \\
2. Calling & 3.52 & .68 & $-.25^{* *}$ & 1.00 & & & & \\
3. WE & 4.24 & .96 & -.57 & $.56^{* *}$ & 1.00 & & & \\
4. Age & 46.5 & 7.0 & .01 & .09 & $.26^{* *}$ & 1.00 & & \\
5. TWCL & 1.97 & .89 & $.27^{* *}$ & .07 & .059 & $.14^{*}$ & 1.00 & \\
6. STS & 2.60 & .68 & $.17^{* *}$ & $.14^{*}$ & $.29^{* *}$ & $.59^{* *}$ & $.43^{* *}$ & 1.00 \\
\hline
\end{tabular}

${ }^{2}$ (TWCL) - Time of work with current leader $(1=>10$ years, $2=5<$ years $<10,3=<5$ years). (STS) - Service time in school $(1=>10$ years, $2=5<$ years $<10,3=<5$ years). (AL) -Authentic Leadership. (WE)-Work Engagement. $\mathrm{N}=326 .{ }^{* *} p<.01$ (2-tailed), ${ }^{*} p<.05$ (2-tailed). 
Table 3.

Results of hierarchical regression analyses, standardized regression coefficients.

\begin{tabular}{|c|c|c|c|c|c|c|c|c|}
\hline \multirow[b]{3}{*}{$\mathrm{N}=326$} & \multicolumn{8}{|c|}{ Authentic Leadership \& Work Engagement \& Calling ${ }^{3}$} \\
\hline & \multicolumn{4}{|c|}{ Work Engagement } & \multicolumn{4}{|c|}{ Calling } \\
\hline & Estimate & SE & $\mathrm{R}^{2}$ adj & $\Delta \mathrm{R}^{2}$ & Estimate & SE & $\mathrm{R}^{2}$ adj. & $\Delta \mathrm{R}^{2}$ \\
\hline Step 1 (Control variables) & & & .09 & $.10^{* * *}$ & & & .01 & .02 \\
\hline Constant & $2.68^{* * *}$ & .35 & & & $3.12^{* * *}$ & .26 & & \\
\hline Age & .13 & .01 & & & .01 & .01 & & \\
\hline TWCL & -.06 & .06 & & & .01 & .05 & & \\
\hline STS & $.24^{* *}$ & .10 & & & .13 & .08 & & \\
\hline Step 2a (Control variables \& AL) & & & .10 & .07 & & & .09 & $.08^{* * *}$ \\
\hline Constant & $3.04^{* * *}$ & .41 & & & $3.96^{* * *}$ & .29 & & \\
\hline Age & .12 & .01 & & & -.02 & .00 & & \\
\hline TWCL & -.04 & .07 & & & .08 & .05 & & \\
\hline STS & $.26^{* *}$ & .10 & & & $.17^{*}$ & .07 & & \\
\hline $\mathrm{AL}$ & -.09 & .08 & & & $-.30^{* * *}$ & .06 & & \\
\hline Step 2b (Control variables \& Calling) & & & .37 & $.28^{* * *}$ & & & & \\
\hline Constant & 0.34 & .35 & & & & & & \\
\hline Age & .12 & .01 & & & & & & \\
\hline TWCL & -.07 & .05 & & & & & & \\
\hline STS & .17 & .09 & & & & & & \\
\hline Calling & $.53^{* * *}$ & .06 & & & & & & \\
\hline Step 3 (interaction AL \& Calling) & & & .24 & $.25^{* * *}$ & & & & \\
\hline Constant & $4.08^{* * *}$ & .22 & & & & & & \\
\hline $\mathrm{AL}$ & $-.46^{* * *}$ & .09 & & & & & & \\
\hline $\mathrm{AL} \times$ Calling & $.64^{* * *}$ & .02 & & & & & & \\
\hline
\end{tabular}

$p<.001$ ). Hypotheses 1 and 2 predicted that there is a positive association between the perceived authentic leadership and follower work engagement and calling. Hypothesis 1 was not supported and we did not find statistically significant results. Hypothesis 2 was not supported either because we found statistically significant negative results $(\beta=-.30, p<.001)$. Hypothesis 3 predicted that there is a positive association between follower calling and work engagement. A significant and positive support was found with statistically significant data ( $\beta$ $=.53, p<.001)$. Hypothesis 4 predicted that the calling of the followers moderates the relationship between authentic leadership and follower work engagement. Hypothesis 4 was supported as being statistically significant $(\beta=.64, p<.001)$.

\section{Discussion and Conclusions}

\section{Making Sense of the Main Findings}

The present study did not confirm the results of previous studies (Avolio \& Gardner, 2005; Eagly, 2005; Gardner, Avolio, Luthans, May, \& Walumbwa, 2005; Ilies, Morgeson \& Nahrgang, 2005; Toor \& Ofori, 2008) in emphasizing the significant effects of perceived authentic leadership in the followers' work

${ }^{3}$ TWCL (Time of work with current leader); STS (Service time in school); AL (Authentic Leadership). ${ }^{* * *} p<.001{ }^{* *} p<.01$ (2-tailed) ${ }^{*} p<.05$ (2-tailed). engagement. We even noticed there was an insignificant negative effect ( $(=-.09)$. This could be explained because followers in that public school context had a specific relationship with leaders. They worked daily with no close control. They only contacted their leaders when there were disciplinary and pedagogical problems or meetings during the year. Thus, they felt free to do their job proposing their own solutions. Begley (2006) proposes three prerequisites to AL in schools: self-knowledge, a capacity for moral reasoning, and sensitivity to the orientation of others. We can also say that AL is not yet a characteristic leadership process in every school. While few school leaders claim to be authentic leaders, there is no empirical research on whether these perceptions are shared by their followers. We can conclude that the followers we have studied did not feel, or perceive AL, as the respondents of other referred studies.

About AL effect on followers' calling, a significant negative effect $(-.30, p<.001)$ was found and it becomes rather strange because, in theory, a positive relationship between AL and calling was expected. In fact, Avolio et al. (2004) suggested that AL increases employees' identification with the organization and the leader, thus fostering employees' positive emotions (as well as trust, hope and calling), which in turn promote their optimism and positive work attitudes, thereby influencing their work engagement.

The predictive power of followers' calling refers to the significant positive effect $(.53, p<.001)$ on work engagement. 
Levels of follower work engagement increased, as levels of calling increased. This is in line with Dobrow (2007) importance of people's subjective perceptions of their abilities in work engagement and we could include calling in the characterization of Csikszentmihalyi "flow-encouraging activities" (1990).

Finally, we conclude that the moderation of calling (.64, $p$ $<.001)$ is also significant in the relationship between AL and Work Engagement. So calling is a powerful variable in the explaining work engagement in our study. Only by creating a caring, concerned and compassionate environment in our schools can school leaders provide the ignition, the calling, needed to the necessary stretch for work engagement. The more calling people have the more work engagement people feel. To be engaged, followers showed that it would be better if they had a calling in their work.

\section{Limitations and Future Research}

Studying a special kind of organization may have produced some cultural biases. Portuguese public schools organizational culture may make teachers less sensitive to authentic leaders than the employees from other organizations.

At present time, we assume that it is quite difficult to perceive the existence of an organizational culture in most of the research schools. Above all, we can envision a shared set of values and behaviours, which are representative of each public school.

For recommendations and information on how to implement the authentic leadership process we refer to the consultancy report "Authentic Leadership-The Leadership Style of the $21^{\text {st }}$ Century" specially written with the use of the research findings of three separate studies on authentic leadership. Within this report, especially the work of George and Sims (2007), which provides a Personal Leadership Development Plan that, was considered as the main guideline for developing authentic leadership within an organization.

Future research should focus on delving deeper into perceived AL within the education public services. This is a fascinating field which is important for a better understanding of public servants', especially teachers', work engagement. We would like to help the foundation of the dynamics needed to promote authentic rather than "contrived collegiality" (Hargreaves, 1994).

Another important area for further research is to address the significant effect of calling on work engagement. The implications would include important issues as vocational education training in subjects like Positive Psychology and NeuroLeadership (Ringleb \& Rock, 2008).

Future studies must also consider other mediating or moderating variables as trust, empowerment, leader-member exchange and employees' authenticity.

\section{Implications for Management and Concluding Remarks}

In spite of some limitations mentioned above, the present study adds to existing literature on authentic leadership by showing results which do not support the existence of a positive relationship between perceived authentic leadership and follower work engagement. Authentic leadership is proven to be valuable for organizations in the "Authentic Leadership-The
Leadership Style of the $21^{\text {st }}$ Century" report. Recommendations indicate the possible influence of culture on the effectiveness of authentic leadership in different countries which could be useful for organizations within different cultures or with aspirations to move to or work with different cultures. Our research does not confirm that relationship and fosters the possibility of AL influence not being felt by employees. In addition, the present study should stimulate leaders to become more authentic which will also induce employees to behave as such to positively stimulate organization performance.

Finally, our study suggests that organizations could promote employee calling work orientations at the initial teacher education stage. According to Schleicher (2012: p. 68), "the predominant model for teacher employment in OECD countries is "career-based" public service in which entry is competitive, career development is extensively regulated and lifetime employment is largely guaranteed ... The quality of the teaching force depends excessively on getting initial recruitment and teacher education right, and that any improvement over time will take many years to affect most serving teachers".

Calling, at least, could be considered as a powerful path for fostering improved organizational work engagement.

\section{REFERENCES}

Amabile, T., Hill, K., Hennessey, B., \& Tighe, E. (1994). The work preference inventory: Assessing intrinsic and extrinsic motivational orientations. Journal of Personality and Social Psychology, 66, 950967. http://dx.doi.org/10.1037/0022-3514.66.5.950

Avery, D., McKay, P., \& Wilson, D. (2007). Engaging the aging workforce: The relationship between perceived age similarity, satisfaction with coworkers, and employee engagement. Journal of Applied Psychology, 92, 1542-1556. http://dx.doi.org/10.1037/0021-9010.92.6.1542

Avolio, B., \& Gardner, W. (2005). Authentic leadership development: getting to the root of positive forms of leadership. The Leadership Quarterly, 16, 315-338. http://dx.doi.org/10.1016/j.leaqua.2005.03.001

Avolio, B., \& Luthans, F. (2006). High impact leader: Moments matter in authentic leadership development. New York: McGraw-Hill.

Avolio, B., Gardner, W., \& Walumbwa, F. (2005). Authentic leadership theory and practice: Origins, effects and development. San Francisco, CA: Elsevier.

Avolio, B., Gardner, W., Walumbwa, F., \& May, D. (2004). Unlocking the mask: A look at the process by which authentic leaders' impact follower attitudes and behaviours. The Leadership Quarterly, 15, 801-823. http://dx.doi.org/10.1016/j.leaqua.2004.09.003

Bakker, A., Albrecht, S., \& Leiter, M. (2011). Key questions regarding work engagement. European Journal of Work and Organizational Psychology, 20, 4-28.

http://dx.doi.org/10.1080/1359432X.2010.485352

Begley, P. (2001). In pursuit of authentic school leadership practices. International Journal of Leadership in Education, 4, 353-365. http://dx.doi.org/10.1080/13603120110078043

Begley, P. (2006). Self-knowledge, capacity and sensitivity: Prerequisites to authentic leadership by school principals. Journal of Educational Administration, 44, 570-589. http://dx.doi.org/10.1108/09578230610704792

Bunderson, J., \& Thompson, J. (2009). The call of the wild: Zookeepers, callings, and the double-edged sword of deeply meaningful work. Administrative Science Quarterly, 54, 32-57. http://dx.doi.org/10.2189/asqu.2009.54.1.32

Buskist, W., Benson, T., \& Sikorski, J. (2005). The call to teach. Journal of Social and Clinical Psychology, 24, 110-121. http://dx.doi.org/10.1521/jscp.24.1.111.59167

Cartwright, S., \& Holmes, N. (2006). The meaning of work: The challenge of regaining employee engagement and reducing cynicism. 
Human Resource Management Review, 16, 199-208.

http://dx.doi.org/10.1016/j.hrmr.2006.03.012

Cattell, R. B. (1966). The scree test for the number of factors. Multivariate Behavioural Research, 1, 245-276. http://dx.doi.org/10.1207/s15327906mbr0102_10

Chalofsky, N. (2003). An emerging construct of meaningful work. Human Resource Development International, 6, 69-83. http://dx.doi.org/10.1080/1367886022000016785

Coetzee, M. (2008). Psychological career resources of working adults: A South African survey. SA Journal of Industrial Psychology, 34, 32-41. http://dx.doi.org/10.4102/sajip.v34i2.491

Csikszentmihalyi, M. (1990). Flow: The psychology of optimal experience. New York: Harper and Row.

Csikszentmihalyi, M. (2003). Good business: Leadership, flow and the making of meaning. New York: Viking.

Dobrow, S. (2007). The development of calling: A longitudinal study of musicians. Proceedings of the Academy of Management Conference, Philadelphia, 1 August 2007, 1-6.

http://dx.doi.org/10.5465/AMBPP.2007.26530582

Duignan, P. (2007). Authentic educative leadership for authentic learning. Learning Matters, 12, 3-8.

Eagly, A. (2005). Achieving relational authenticity in leadership: Does gender matter? The Leadership Quarterly, 16, 459-474. http://dx.doi.org/10.1016/j.leaqua.2005.03.007

Frankl, V. E. (1984). Man's search for meaning (3rd ed.). New York: Pocket Books.

Gardner, W., Avolio, B., \& Walumbwa, F. (2005). Authentic leadership development: Emergent themes and future directions. Leadership and Management, 3, 387-406.

Gardner, W., Avolio, B., Luthans, F., May, D., \& Walumbwa, F. (2005). Can you see the real me? A self-based model of authentic leader and follower development. The Leadership Quarterly, 16, 343-372. http://dx.doi.org/10.1016/j.leaqua.2005.03.003

George, W., \& Sims, P. (2007). True north: Discovering your authentic Leadership. San Francisco, CA: Jossey-Bass.

Gilbert, D. (1991). How mental systems believe. American Psychologist, 46, 107-119. http://dx.doi.org/10.1037/0003-066X.46.2.107

Hall, D., \& Chandler D. (2005). Psychological success: When the career is a calling. Journal of Organizational Behavior, 26, 155-176. http://dx.doi.org/10.1002/job.301

Hargreaves, A. (1994). Changing teachers, changing times: teachers' work and culture in the postmodern age. New York: Teachers College Pres.

Harrison, D. A., Newman, D. A., \& Roth, P. L. (2006). How important are the job attitudes? Meta-analytic comparisons of integrative behavioral outcomes and time sequences. Academy of Management Journal, 49, 305-325. http://dx.doi.org/10.5465/AMJ.2006.20786077

Hox, J. (2002). Multilevel analysis: Techniques and applications. New Jersey, London: Lawrence Erlbaum Associates, Publishers.

Ilies, R., Morgeson, F., \& Nahrgang, J. (2005). Authentic leadership and eudaemonic well-being: Understanding leader-follower outcomes. The Leadership Quarterly, 16, 373-394. http://dx.doi.org/10.1016/j.leaqua.2005.03.002

Kahn, W. (1990). Psychological conditions of personal engagement and disengagement at work. Academy of Management Journal, 33, 692724. http://dx.doi.org/10.2307/256287

Kets De Vries, M. F. R. (2001). Creating authentizotic organizations: Well-functioning individuals in vibrant companies. Human Relations, 54, 101-111. http://dx.doi.org/10.1177/0018726701541013

Lord, R. G., \& Maher, K. J. (1994). Leadership and information processing: Linking perceptions and organizational performance (New ed.). New York: Routledge, Chapman Hall.

Loscocco, K., \& Roschelle, A. (1991). Influences on the quality of work and nonwork life: Two decades in review. Journal of Vocational Behavior, 39, 182-225.

http://dx.doi.org/10.1016/0001-8791(91)90009-B

Luthans, F., \& Avolio, B. (2003). Authentic leadership development. In K. S. Cameron, S. E. Dutton, \& R. E. Quinn (Eds.), Positive organizational scholarship_Foundations of a new discipline (pp. 241-258). San Francisco, CA: Berrett-Koehler.

Luthans, F., Norman, S., \& Hughes, L. (2006). Authentic leadership. In
R. Burke, \& C. Cooper (Eds.), Inspiring leaders (pp. 84-104). London: Routledge, Taylor \& Francis.

May, D., Gilson, R., \& Harter, L. (1999). Engaging the human spirit at work: Exploring the psychological conditions of meaningfulness, safety, and availability. Chicago, IL: The Academy of Management.

Michie, S., \& Gooty, J. (2005). Values, emotions, and authenticity: Will the real leader please stand up? The Leadership Quarterly, 16, 441-457. http://dx.doi.org/10.1016/j.leaqua.2005.03.006

Pallant, J. (2007). SPSS survival manual (Vol. 179). Berkshire: Open University Press.

Peterson, C., \& Seligman, M. (2003). Positive organizational studies: Lessons from positive psychology. In K. Cameron, J. Dutton, \& R. Quinn (Eds.), Positive organizational scholarship: Foundations of a new discipline (pp. 14-28). San Francisco, CA: Berrett-Koeller.

Ringleb, A., \& Rock, D. (2008). The emerging field of NeuroLeadership. NeuroLeadership Journal, 1, 3-19.

Schaufeli, W. B., Salanova, M., Gonzalez-Romá, V., \& Bakker, A. B. (2002). The measurement of engagement and burnout: A confirmative analytic approach. Journal of Happiness Studies, 3, 71-92. http://dx.doi.org/10.1023/A:1015630930326

Schaufeli, W., \& Bakker, A. (2003). Utrecht work engagement scale: Preliminary manual. Utrecht: Occupational Health Psychology Unit, Utrecht University.

Schaufeli, W., Bakker, A., \& Salanova, M. (2006). The measurement of work engagement with a short questionnaire-A cross-national study. Educational and Psychological Measurement, 66, 701-716. http://dx.doi.org/10.1177/0013164405282471

Schaufeli, W., \& Salanova, M. (2007). Work engagement: An emerging psychological concept and its implications for organizations. In S. W. Gilliland, D. D. Steiner, \& D. P. Skarlicki (Eds.), Research in social issues in management (Volume 5): Managing social and ethical issues in organizations (pp. 135-177). Greenwich, CT: Information Age Publishers.

Schaufeli, W., \& Salanova, M. (2011). Work engagement: On how to better catch a slippery concept. European Journal of Work \& Organizational Psychology, 20, 39-46. http://dx.doi.org/10.1080/1359432X.2010.515981

Schleicher, A. (2012). Preparing teachers and developing school leaders for the 21st century: Lessons from around the world. Paris: OECD Publishing. http://dx.doi.org/10.1787/9789264174559-en

Seligman, M., \& Csikszentmihalyi, M. (2000). Positive psychology: An introduction. American Psychologist, 55, 5-14. http://dx.doi.org/10.1037/0003-066X.55.1.5

Spitzmuller, M., \& Ilies, R. (2010). Do they [all] see my true self? Leader's relational authenticity and followers' assessments of transformational leadership. European Journal of Work and Organizational Psychology, 19, 304-332.

http://dx.doi.org/10.1037/0003-066X.55.1.5

Starratt, R. (2004). Ethical leadership. San Francisco, CA: Jossey-Bass.

Toor, S.-U.-R., \& Ofori, G. (2008). Leadership for future construction industry: Agenda for authentic leadership. International Journal of Project Management, 26, 620-630. http://dx.doi.org/10.1016/j.ijproman.2007.09.010

Walumbwa, F., Avolio, B., Gardner, W., Wernsing, T., \& Peterson, S. (2008). Authentic Leadership: Development and validation of a theory-based measure. Journal of Management, 34, 89-126. http://dx.doi.org/10.1177/0149206307308913

Weiss, J., Skelley, M., Haughey, J., \& Hall, D. (2003). Calling, new careers and spirituality: A reflective perspective for organizational leaders and professionals. In M. Pava, \& Patrick Primeaux (Eds.), Spiritual intelligence at work: Meaning, metaphor, and morals (Research in Ethical Issues in Organizations, Volume 5) (pp.175-201). Bingley: Emerald Group Publishing Limited.

Wrzesniewski, A. McCauley, C., Rozin, P., \& Schwartz, B. (1997). Jobs, careers, and callings: People's relations to their work. Journal of Research in Personality, 31, 21-33. http://dx.doi.org/10.1006/jrpe.1997.2162

Yan, J., \& Hunt, J. (2005). A cross cultural perspective on perceived leadership effectiveness. International Journal of Cross Cultural Management, 5, 49-66. http://dx.doi.org/10.1177/1470595805050824 